\title{
Pengaruh Perbedaan Aras Aspergillus niger dan Lama Peram terhadap Kecernaan Protein Kasar dan Serat Kasar Fermentasi Kelobot Jagung Amoniasi secara in vitro
}

\author{
The Effect of Different Levels of Aspergillus niger and Fermentation Duration on Crude Protein \\ Digestibility and Crude Fiber of Fermented Corn Husk in vitro
}

\section{Ahmad, B. I. M. Tampoebolon dan A. Subrata}

Fakultas Peternakan dan Pertanian, Universitas Diponegoro

Corresponding Author: mecka.achmad@gmail.com

\begin{abstract}
This research aimed to examined the effect of combination treatments of the level of Aspergillus niger (A. niger) and incubation time corn husk amoniated on crude protein (CP) and crude fiber (CF) digestibility. This research used a completely randomized factorial pattern design $3 \times 3$, with the treatments of $A$. niger levels $(0,2.5$ and 5 $\%$ DM) and incubation durations (0, 7 and 14 days) with 3 replications of each treatment. The parameters observed were CP and CF digestibility. Materials used in the research were corn husk, urea, A. niger mold and ruminal fluid. Procedures used in research were preparation of amoniation of corn husk used $6 \%$ of ammonia level on $60^{\circ} \mathrm{C}$ temperature with 4 days incubation time, next was fermentation, then analyzed corn husk used in vitro digestibility test also analyzed CP and CF tests. The data analyzed used ANOVA and if the result was significant, continued with Duncan's multiple range test. The result showed that the interaction of A. niger level and incubation time had a significant $(\mathrm{p}<0.05)$ increased $\mathrm{CP}$ and $\mathrm{CF}$ digestibility. Aspergillus niger $5 \%$ level and 14 days incubation time showed the best result on CP digestibility with $63.07 \%$ and CF digestibility with $54.39 \%$. The conclusion were combination of A. Niger level and incubation time increased CP and CF digestibility on corn husk.
\end{abstract}

Key words : corn husk, fermentation, digestibility, crude protein, crude fiber

\begin{abstract}
ABSTRAK
Penelitian bertujuan untuk mengkaji pengaruh kombinasi perlakuan antara aras Aspergillus niger (A. niger) dan lama peram dalam fermentasi kelobot jagung amoniasi terhadap kecernaan protein kasar (KcPK) dan kecernaan serat kasar (KcSK). Penelitian dilaksanakan menggunakan rancangan acak lengkap pola faktorial $3 \times 3$, dengan perlakuan aras A. niger (0, 2.5 dan 5\% BK) sebagai faktor pertama dan lama peram (0, 7 dan 14hari) sebagai faktor kedua dan diulang sebanyak 3 kali untuk setiap perlakuan. Parameter yang diamati adalah KcPK dan KcSK. Materi yang digunakan yaitu kelobot jagung, urea, kapang A. niger dan cairan rumen sapi. Metode yang dilakukan yaitu melakukan amoniasi kelobot jagung dengan kadar amonia $6 \%$ pada suhu $60^{\circ} \mathrm{C}$ selama 4 hari, kemudian dilanjutkan proses fermentasi, setelah itu dilakukan uji kecernaan in vitro serta uji protein kasar dan serat kasar. Data yang diperoleh dianalisis menggunakan ANOVA dan jika hasilnya signifikan maka dilanjutkan dengan uji wilayah ganda Duncan. Hasil penelitian menunjukkan bahwa perlakuan kombinasi antara aras A. niger dan lama peram ada interaksi nyata $(\mathrm{p}<0,05)$ meningkatkan KcPK dan KcSK. Perlakuan aras A. niger 5\% dengan lama peram 14 hari menghasilkan kecernaan yang terbaik ditinjau dari nilai KcPK 63,07\% dan KcSK 54,39\%. Berdasarkan hasil penelitian dapat disimpulkan bahwa kombinasi perlakuan antara aras A. niger dan lama peram dapat meningkatkan KcPK dan KcSK kelobot jagung fermentasi.
\end{abstract}

Kata kunci : kelobot jagung, fermentasi, kecernaan, protein kasar, serat kasar

\section{PENDAHULUAN}

Pakan merupakan faktor utama dalam mempengaruhi usaha peternakan. Penyediaan pakan alternatif sebagai sumber serat bagi ruminansia perlu ditingkatkan karena penyediaan hijauan semakin sulit dilakukan akibat curah hujan yang tidak merata sepanjang tahun sehingga mengakibatkan produksi hijauan pakan di musim kemarau menurun. Solusi dari permasalahan tersebut dengan menggunakan hasil samping pertanian, salah satunya adalah kelobot jagung.

Kelobot jagung merupakan sisa hasil pertanian yang mempunyai potensi cukup besar sebagai pakan ternak. Menurut data yang diperoleh dari Tribunnews (27/9/2018), 
produksi jagung di Indonesia tahun 2018 berdasarkan angka ramalan Badan Pusat Statistik (ARAM 1, BPS 2018) mencapai 30 juta ton jagung pipil kering dengan luas tanam 9,8 juta $\mathrm{Ha}$, dengan perkiraan produksi jagung pipil kering per Ha adalah 3,06 ton.

Kelobot jagung memiliki proporsi $10 \%$ dari total bagian tanaman jagung, sedangkan tongkol jagung memiliki proporsi 20\%. Berdasarkan data tersebut, dapat diperkirakan bahwa produksi kelobot jagung di Indonesia dapat mencapai $\pm 1,53$ ton BK / Ha dalam sekali panen. Hal ini merupakan salah satu faktor yang menyebabkan kelobot jagung memiliki potensi sebagai pakan alternatif ditinjau dari kuantitasnya.

Pemanfaatan kelobot jagung sebagai sumber serat tidak menggantikan seluruh fungsi rumput sebagai pakan sumber serat, melainkan hanya 50\% dari total kebutuhan serat. Pemberian pakan dalam peternakan umumnya terdiri atas $40 \%$ konsentrat dan $60 \%$ hijauan, bila penggunan kelobot menggantikan $50 \%$ dari rumput, maka jumlah produksi kelobot jagung nasional per tahun dapat menopang hingga \pm 13 juta (13.038.260) jumlah ternak.

Kelobot jagung masih dapat digunakan sebagai pakan ternak ruminansia karena memiliki kandungan serat kasar $48,19 \%$, protein $5,33 \%$, dan lemak kasar $0,61 \%$ (Syananta, 2009), serta pada serat kasar mengandung 48,6\% selulosa, 16,1\% hemiselulosa dan 6,5\% lignin (Valdebenito et al., 2016). Kelobot jagung mempunyai kandungan protein yang rendah serta kadar serat kasar dan lignin yang tinggi, sehingga kelobot jagung belum dapat digunakan sebagai pakan utama, sehingga dalam pemanfaatan kelobot jagung sebagai pakan perlu ditingkatkan kualitasnya melalui pengolahan amoniasi dan fermentasi.

Teknologi pengolahan pakan dengan amoniasi dan fermentasi bertujuan untuk menurunkan kadar serat dan meningkatkan kecernaan yaitu dengan adanya amoniasi akan mengakibatkan ikatan lignin dengan selulosa maupun hemiselulosa menjadi renggang (Komar, 1984), sehingga enzim menjadi lebih mudah untuk memecah serat serta meningkatkan kecernaan bahan pakan (Stanbury dan Whitaker, 1984; Mirni et al., 2006).

\section{MATERI DAN METODE}

Penelitian dilaksanakan pada bulan Juni sampai dengan bulan Desember 2017. Penelitian ini dilakukan secara in vitro yang dilaksanakan di Laboratorium Teknologi Pakan serta Laboratorium Ilmu Nutrisi danPakan, Departemen Peternakan, Fakultas Peternakan dan Pertanian, Universitas Diponegoro, Semarang.

Materi yang digunakan dalam penelitian yaitu kelobot jagung, urea, starter berupa kapang $A$. niger, akuades, alkohol 90\%, cairan rumen sapi, cairan McDougal, cairan pepsin $\mathrm{HCl}$, akuades, gas $\mathrm{CO}_{2}, \mathrm{H}_{2} \mathrm{SO}_{4}$ $0,3 \mathrm{~N}, \mathrm{NaOH} 1,5 \mathrm{~N}$, aseton, $\mathrm{H}_{2} \mathrm{SO}_{4}$ pekat, $\mathrm{H}_{3} \mathrm{BO}_{4} 4 \%, \mathrm{KHSO}_{4}, \mathrm{CuSO}_{4}$, indikator (metil merah dan metil biru), $\mathrm{NaOH} 45 \%$ dan $\mathrm{HCl}$ $0,1 \mathrm{~N}$.

Peralatan yang digunakan yaitu alat pemotong, timbangan digital, nampan, toples kaca ukuran $350 \mathrm{ml}$, inkubator, bunsen, spuit, blender, panci, kompor, plastik wrap, plastik klip, kertas label, alat tulis, tabung fermentor beserta tutupnya, tabung reaksi, beaker glass, water bath, corong, sentrifuse, timbangan merek ohaus dengan ketelitian 0,0001 g, cawan petri, desikator, penjepit cawan, oven, tanur pengabuan, Erlenmeyer $600 \mathrm{ml}$, pendingin balik, kertas saring, kapas, alat destilasi, buret, pipet ukur, Erlenmeyer 100 $\mathrm{ml}$, beaker glass, pipet tetes.

Metode yang digunakan dalam penelitian meliputi rancangan penelitian, prosedur penelitian dan analisis data.

\section{Prosedur Penelitian}

Kegiatan penelitian terbagi dalam empat tahapan, yaitu tahap persiapan, pembuatan amoniasi, perlakuan fermentasi, dan analisis laboratorium (uji kecernaan in vitro serta uji protein kasar dan serat kasar). Tahap persiapan meliputi pembiakan (enrichment) kapang $A$. niger yang akan digunakan sebagai starter fermentasi, serta peralatan dan bahan yang akan digunakan dalam melakukan penelitian. 
Tahap pembuatan amoniasi kelobot jagung menurut metode Komar (1984) yang dimodifikasi menurut Utomo (2015), dilakukan dengan cara basah menggunakan suhu peram $60^{\circ} \mathrm{C}$ dengan kadar ammonia $6 \%$ dan lama peram 4 hari.

Tahap fermentasi dilakukan dengan penggunaan aras $A$. niger $0,2,5$ dan $5 \%$ terhadap bahan kering (BK) dengan lama peram 0,7 , dan14 hari.

Tahap analisis laboratorium secara in vitro menggunakan cairan rumendilakukan menurut metode Tilley dan Terry (1963), setelah itu dilanjutkan dengan uji protein kasar menurut metode kejdahl di dalam AOAC (2005) dan serat kasar menurut metode AOAC (2005) untuk mengetahui KcSK dan KcSK.

\section{Rancangan Penelitian}

Rancangan penelitian yang digunakan adalah rancangan acak lengkap (RAL) pola faktorial 3 x 3 . Faktor perlakuan pertama adalah aras $A$. niger $\mathrm{M}_{0}(0 \%), \mathrm{M}_{1}(2,5 \%)$, dan $\mathrm{M}_{2}(5 \%)$ sedangkan faktor kedua adalah lama peram yaitu $\mathrm{T}_{0}(0$ hari $), \mathrm{T}_{1}$ (7 hari) dan $\mathrm{T}_{2}$ (14 hari) dengan 3 ulangan pada masingmasing perlakuan. Kombinasi perlakuan sebagai berikut :

$\mathrm{M}_{0} \mathrm{~T}_{0}=$ kelobot jagung amoniasi + A. niger $0 \%+$ lama peram 0 hari

$\mathrm{M}_{0} \mathrm{~T}_{1}=$ kelobot jagung amoniasi + A. niger $0 \%+$ lama peram 7 hari

$\mathrm{M}_{0} \mathrm{~T}_{2}=$ kelobot jagung amoniasi + A. niger $0 \%+$ lama peram 14 hari

$\mathrm{M}_{1} \mathrm{~T}_{0}=$ kelobot jagung amoniasi + A. niger $2,5 \%$ + lama peram 0 hari

$\mathrm{M}_{1} \mathrm{~T}_{1}=$ kelobot jagung amoniasi + A. niger 2,5\% + lama peram 7 hari

$\mathrm{M}_{1} \mathrm{~T}_{2}=$ kelobot jagung amoniasi + A. niger $2 \%+$ lama peram 14 hari

$\mathrm{M}_{2} \mathrm{~T}_{0}=$ kelobot jagung amoniasi + A. niger $5 \%+$ lama peram 0 hari

$\mathrm{M}_{2} \mathrm{~T}_{1}=$ kelobot jagung amoniasi + A. niger $5 \%+$ lama peram 7 hari

$\mathrm{M}_{2} \mathrm{~T}_{2}=$ kelobot jagung amoniasi + A. niger $5 \%+$ lama peram 14 hari

Analisis data menggunakan analisis sidik ragam (Anova) taraf signifikansi 5\% untuk mengetahui pengaruh interaksi perlakuan. Apabila terdapat pengaruh maka dilakukan uji lanjut yaitu uji wilayah ganda Duncan untuk mengetahui perbedaan nilai tengah antar perlakuan (Steel dan Torrie, 1991).

\section{HASIL DAN PEMBAHASAN}

\section{Kecernaan Protein Kasar Kelobot Jagung Fermentasi}

Hasil penelitian tentang pengaruh aras A. Niger dan lama peram terhadap KcPK kelobot jagung amoniasi disajikan pada Tabel 1. Rata-rata nilai KcPK kelobot jagung amoniasi yang di fermentasi lebih tinggi daripada perlakuan kontrol (tanpa perlakuan fermentasi), semakin lama peram dan semakin tinggi aras starter akan meningkatkan nilai KcPK.

Tabel 1. Rata-rata nilai KcPK

\begin{tabular}{|c|c|c|c|c|}
\hline \multirow{2}{*}{$\begin{array}{c}\text { Aras } A . \\
\text { niger } \\
(\%)\end{array}$} & \multicolumn{3}{|c|}{ Lama Peram (hari) } & \multirow[b]{2}{*}{ Rataan } \\
\hline & $\mathrm{T}_{0}$ & $\mathrm{~T}_{1}$ & $\mathrm{~T}_{2}$ & \\
\hline & & $--(\%)--$ & & --------- \\
\hline $\mathbf{M}_{0}$ & $51,02^{\mathrm{f}}$ & $52,19^{\mathrm{ef}}$ & $52,33^{\mathrm{e}}$ & 51,85 \\
\hline $\mathrm{M}_{1}$ & $52,48^{\mathrm{e}}$ & $54,35^{\mathrm{d}}$ & $57,87^{\mathrm{c}}$ & 54,90 \\
\hline $\mathrm{M}_{2}$ & $54,26^{\mathrm{d}}$ & $59,24^{\mathrm{b}}$ & $63,07^{\mathrm{a}}$ & 58,86 \\
\hline Rataan & 52,59 & 55,26 & 57,76 & \\
\hline
\end{tabular}

Berdasarkan Tabel 1 dapat diketahui bahwa perlakuan terbaik yaitu pada $\mathrm{M}_{2} \mathrm{~T}_{2}$ $(63,07 \%)$ yaitu dengan aras $5 \%$ serta lama peram14hari, sedangkan hasil terendah pada $\mathrm{M}_{0} \mathrm{~T}_{0}(51,02 \%)$ yaitu dengan aras $0 \%$ serta lama peram 0 hari. Hasil ini menunjukkan bahwa lama waktu peram serta aras starter hingga 5\% secara bersama-sama dapat meningkatkan KcPK secara in vitro. Hal ini diduga karena terjadi biokonversi pakan akibat dari fermentasi sehingga kecernaan semakin baik, serta terjadi peningkatan $\mathrm{KcSK}$ yang berpengaruh terhadap KcPK terutama protein yang terikat pada dinding sel. Meningkatnya kecernaan serat kasar akibat menurunnya kadar serat dan terjadinya dekomposisi serat saat fermentasi.

Meningkatnya KcPK dapat terjadi karena aktivitas fermentasi $A$. niger ikut meningkatkan kadar protein serta kecernaan 
kelobot, selain itu karenaKcPK ikut dipengaruhi oleh kadar serat kasar serta kadar protein mudah dicerna dalam pakan. Hal ini sesuai dengan pendapat De Vries dan Visser (2001) yang menyatakan bahwa $A$. Niger memiliki karakteristik yang ideal untuk digunakan dalam aplikasi berskala industri, karena kemampuan fermentasinya yang baik serta peningkatan sekresi enzim yang tinggi. Despal (2000) menyatakan bahwa estimasi tingkat kecernaan pakan dapat dilihat dari kandungan serat kasar pakan.

Peningkatan KcPK dapat terjadi karena kapang $A$. niger menghasilkan enzim yang mendegradasi serat kasar, sehingga kadar serat kasar menurun. Aras A. niger yang lebih tinggi menghasilkan nilai KcPK yang lebih tinggi karena dalam waktu yang sama perlakuan $A$. niger pada aras yang lebih tinggi menghasilkan jumlah yang lebih banyak sehingga kerja enzim yang dihasilkan menjadi lebih baik untuk mendegradasi serat.

Hal ini sesuai dengan pendapat Nurhayati et al. (2014) yang menyatakan bahwa penggunaan aras tinggi hingga kadar tertentu serta lama peram yang cukup akan meningkatkan nilai kecernaan bahan pakan yang difermentasi karena bakteri membutuhkan proses untuk tumbuh dalam jangka waktu tertentu. Itelima et al. (2013) menyatakan bahwa fermentasi aras A. niger dan $S$. cerevisiae pada kulit nanas yang dilaksanakan selama 7 hari meningkatkan jumlah mikroorganisme yang lebih banyak daripada dengan kontrol waktu yang lebih pendek.

\section{Kecernaan Serat Kasar Kelobot Jagung Fermentasi}

Hasil penelitian tentang pengaruh aras A. niger dan lama peram terhadap KcSK kelobot jagung amoniasi disajikan pada Tabel 2. Rata-rata nilai KcSK kelobot jagung amoniasi yang di fermentasi lebih tinggi daripada perlakuan kontrol (tanpa perlakuan fermentasi), semakin lama waktu peram dan semakin tinggi aras starter dapat meningkatkan nilai KcSK.
Tabel 2. Rata-rata nilai KcSK

\begin{tabular}{|c|c|c|c|c|}
\hline \multirow{2}{*}{$\begin{array}{c}\text { Aras } A . \\
\text { niger } \\
(\%)\end{array}$} & \multicolumn{3}{|c|}{ Lama Peram (hari) } & \multirow{2}{*}{ Rataan } \\
\hline & $\mathrm{T}_{0}$ & $\mathrm{~T}_{1}$ & $\mathrm{~T}_{2}$ & \\
\hline$M_{0}$ & $\Delta 0 \Delta 7^{\mathrm{f}}$ & $4145^{\mathrm{ef}}$ & $4183^{\mathrm{e}}$ & 4125 \\
\hline $\begin{array}{l}\mathrm{M}_{0} \\
\mathrm{M}_{1}\end{array}$ & $\begin{array}{l}40,47 \\
42.11^{\mathrm{e}}\end{array}$ & $\begin{array}{l}41,45 \\
44.07^{d}\end{array}$ & $\begin{array}{l}41,85 \\
47.06^{\mathrm{c}}\end{array}$ & $\begin{array}{l}41,25 \\
44,41\end{array}$ \\
\hline $\mathrm{M}_{2}$ & $43,46^{\mathrm{d}}$ & $50,19^{\mathrm{b}}$ & $54,39^{\mathrm{a}}$ & 49,35 \\
\hline
\end{tabular}

Superskrip yang berbeda pada baris dan kolom yang berbeda menunjukkan perbedaan nyata $(\mathrm{P}<0,05)$

Berdasarkan Tabel 2 dapat diketahui bahwa perlakuan terbaik yaitu pada $\mathrm{M}_{2} \mathrm{~T}_{2}$ $(54,39 \%)$ yaitu dengan aras $5 \%$ serta lama peram 14 hari, sedangkan hasil terendah pada $\mathrm{M}_{0} \mathrm{~T}_{0}(40,47 \%)$ yaitu dengan aras $0 \%$ serta lama peram 0 hari. Hasil ini menunjukkan bahwa lama waktu peram serta kadar aras hingga 5\% dapat meningkatkan KcSK secara in vitro. Hal ini diduga karena peningkatan starter yang tinggi mengakibatkan peningkatan jumlah sel yang lebih banyak, sehingga dalam waktu yang sama perlakuan A. niger pada aras yang lebih tinggi menghasilkan jumlah yang lebih banyak serta kerja enzim yang dihasilkan menjadi lebih baik. Proses fermentasi dari A. niger mengurangi ikatan kristal antara lignin dengan selulosa maupun hemiselulosa akibat dari adanya aktivitas sekresi enzim selulase sehingga dapat meningkatkan KcSK.

Hal ini sesuai dengan pendapat Tampoebolon (2015) yang menyatakan bahwa bahan pakan berserat yang diberikan pada ternak ruminansia tidak optimal karena sebagian besar selulosa dan hemiselulosa berikatan dengan lignin yang sulit untuk dicerna. Menurut De Vries dan Visser (2001) yang menyatakan bahwa Aspergillus dalam melakukan biodegradasi menghasilkan 3 enzim, yaitu endoglukanase, eksoglukanase, serta $\beta$-Glukosidase. Menurut Gong dan Tsao di dalam Perlman (1979) yang menyatakan bahwa ada tiga jenis enzim dalam kompleks enzim selulosa yang memiliki peran menghidrolisis selulosa, yaitu endoglukanase atau endoselulase yang dapat menyerang polimer selulosa dari dalam secara acak, eksoglukanase atau eksoselulase yang menyerang selulosa dengan pola dari ujung non pereduksi dan menghasilkan unit 
selobiosa sebagai satu-satunya hasil hidrolisis serta enzim ini lebih aktif pada selulosa kristal, dan $\beta$-Glukosidase atau selobiase yang menghidrolisis selobiosa menjadi glukosa. Faktor yang mempengaruhi nilai kecernaan serat kasar pada kelobot jagung yaitu ikatan kristal antara lignin dengan selulosa maupun hemiselulosa. Menurut Amin et al. (2016) menyatakan bahwa faktor yang sangat mempengaruhi tinggi rendahnya daya cerna jerami yaitu kandungan lignin, karena proses lignifikasi akibat dari jaringan tanaman yang sudah tua membuat ikatan antara selulosa dan lignin serta hemiselulosa dan lignin menjadi kuat, sehingga usaha untuk meningkatkan kandungan nutriennya perlu dilakukan perlakuan kombinasi antara fisik, kimia dan biologi.

Hasil penelitian yang diperoleh dapat diketahui bahwa interkasi perlakuan aras starter A. niger dan lama peram secara umum dapat meningkatkan KcSK pada kelobot jagung amoniasi. Hal ini diduga karena peningkatan starter yang tinggi mengakibatkan peningkatan jumlah sel yang lebih banyak, sehingga dalam waktu yang sama perlakuan $A$. niger pada aras yang lebih tinggi menghasilkan jumlah yang lebih banyak serta kerja enzim yang dihasilkan menjadi lebih baik. Fermentasi dapat meningkatkan KcSK karena bekerja sebagai dekomposisi dari senyawa komplek diubah menjadi lebih sederhana sehingga lebih mudah dicerna, serta terjadi proses delignifikasi dan desilifikasi serat yaitu proses pelepasan ikatan lignin maupun ikatan silika sehingga lebih mudah dicerna.

Hal ini sesuai dengan pendapat Nurhayati et al. (2014) yang menyatakan bahwa penggunaan aras tinggi hingga kadar tertentu serta lama peram yang cukup akan meningkatkan nilai kecernaan bahan pakan yang difermentasi karena bakteri membutuhkan proses untuk tumbuh dalam jangka waktu tertentu. Itelima et al. (2013) menyatakan bahwa fermentasi aras $A$. niger dan $S$. cerevisiae pada kulit nanas yang dilaksanakan selama 7 hari meningkatkan jumlah mikroorganisme yang lebih banyak daripada dengan kontrol waktu yang lebih pendek.

\section{KESIMPULAN}

Berdasarkan hasil penelitian dapat disimpulkan bahwa kombinasi perlakuan antara aras $A$. niger dengan lama peram dapat meningkatkan KcPK dan KcSK. Perlakuan yang memiliki hasil kombinasi terbaik yaitu dengan penggunaan aras $A$. niger sebanyak 5\% dan lama peram14 hari yang memiliki data masing-masing nilai KcPK63,07\% dan nilai KcSK 54,39\%.

\section{DAFTAR PUSTAKA}

Amin, M., S. D. Hasan, O. Yanuarianto, M. Iqbal dan I. W. Karda. 2016. Peningkatan kualitas jerami padi menggunakan teknologi amoniasi fermentasi. J. Ilmu dan Teknologi Peternakan Indonesia 2 (1) : 96103.

AOAC, 2005. Official Methods of Analysis (18th Ed). Association of Official Analytical Chemists, Gaithersburg.

De Vries, R.P. dan J.A.A.P. Visser. 2001. Aspergillus enzymes involved in degradation of plant cell wall polysaccharides. J. Microbiology and Molecular Biology Reviews 65 (4): $497-$ 552.

Despal. 2000. Kemampuan komposisi kimia dan kecernaan in vitro dalam mengestimasi kecernaan in vivo. Media Peternakan 23 (3): $84-88$.

Itelima, J., F. Onwuliri, E. Onwuliri, I. Onyimba and S. Oforji. 2013. Bio-ethanol production from banana, plantain and pineapple peels by simultaneous saccharification and fermentation process. Int. J. Environ. Sci. Dev. 4: 213-216.

Komar, A. 1984. Teknologi Pengolahan Jerami Sebagai Makanan Ternak. Yayasan Dian Grahita, Bandung.

Mirni, L., Puspaningsih, N. N. T., Chusniati, S. 2006. Penggunaan bakteri xilanolitik asal rumen sebagai inokulum pada jerami padi sebagai upaya peningkatan mutu pakan ternak ruminansia. Lembaga Penelitian. 
Universitas Airlangga, Surabaya. (Tidak Dipublikasikan).

Nurhayati., Nelwida dan Berliana. 2014. Pengaruh tingkat yogurt dan waktu fermentasi terhadap kecernaan in vitro bahan kering, bahan organik, protein, dan serat kasar kulit nanas fermentasi. Buletin Peternakan 38 (3): 182-188.

Perlman, D. 1979. Annual Reports on Fermentation Processes, Volume 3 . Academic Press, New York.

Stanbury, P.F., and A. Whitaker. 1984. Principle of Fermentation Technology. Pergamon Press Ltd, Oxford.

Steel, R. G. D. dan J. H. Torrie. 1991. Prinsip dan Prosedur Statistika Suatu Pendekatan Biometrik (Terjemahan : B. Sumantri). Gramedia, Jakarta.

Syananta, F. P. 2009. Uji Sifat Fisik Wafer Limbah Sayuran Pasar dan Palatabilitasnya pada Ternak Domba. Institut Pertanian
Bogor, Bogor. (Skripsi Sarjana Peternakan).

Tampoebolon, B. I. M. 2015. Peningkatan Kualitas Jerami Padi melalui Teknologi Fermentasi Menggunakan Mikroba Pencerna Serat dari Rayap (Cryptotermes sp.). Universitas Gadjah Mada, Yogyakarta. [Desertasi].

Tilley, J. M. A. dan Terry R.A. 1963. A twostage technique for the in vitro digestion of forage crops. J. Brit. Grassland 18 : 104111.

Utomo, R. 2015. Konversi Hijauan Pakan dan Peningkatan Kualitas Bahan Pakan Berserat Tinggi. Gadjah Mada University Pres, Yogyakarta.

Valdebenito, F., M. Pereira, G. Ciudad, L. Azocar, R. Briones, G. Chinga dan Carrasco. 2016. On the nano fibrillation of corn husks and oat hulls fibres. J. Industrial Crops and Products 95 : 528534. 